\title{
Trastuzumab: A Milestone in Human Epidermal Growth Factor Receptor 2-Positive Breast Cancer
}

\begin{abstract}
Human epidermal growth factor receptor 2 (HER2) overexpression is seen in $25 \%$ of breast cancers. Patients with HER2-positive breast cancer have aggressive disease and inferior survival. HER2 overexpression is assessed by immunohistochemistry or fluorescent in situ hybridization-based methods. Trastuzumab has shown to improve survival in HER2-positive breast cancer. It is recommended in patients with $>\mathrm{T} 1 \mathrm{c}$ for 1-year duration in adjuvant setting, preferably given concurrently with taxane.
\end{abstract}

Keywords: Breast cancer, human epidermal growth factor receptor 2-positive disease, trastuzumab

\section{Introduction}

Human epidermal growth factor receptor 2 (HER2) overexpression is seen in $25 \%$ of breast cancers. ${ }^{[1]}$ Patients with HER2-positive breast cancer have aggressive disease, higher chance of metastasis, and inferior survival. ${ }^{[2]}$ HER2 overexpression is assessed by immunohistochemistry (IHC) or fluorescent in situ hybridization (FISH)-based methods. Trastuzumab has shown to improve survival in HER2-positive breast cancer.

\section{Mechanism of Action}

Trastuzumab is an $\operatorname{IgG}_{1}$ kappa recombinant DNA-derived humanized monoclonal antibody that selectively binds with high affinity to the extracellular domain of (HER2) protein and prevents the activation of intracellular tyrosine kinase. Other mechanisms include prevention of HER2 receptor dimerization, increased endocytic destruction of receptor, and antibody-dependent cell-mediated cytotoxicity. ${ }^{[3]}$ There are a few differences in the mechanism of action between trastuzumab and newer anti-HER2 therapy. Pertuzumab binds to subdomain 2 of HER2 receptors and blocks its ligand-dependent heterodimerization with HER1, HER3, and HER4. Lapatinib binds to the intracellular domain of epidermal growth factor receptor and HER2 and prevents the downstream signaling.

This is an open access journal, and articles are distributed under the terms of the Creative Commons Attribution-NonCommercial-ShareAlike 4.0 License, which allows others to remix, tweak, and build upon the work non-commercially, as long as appropriate credit is given and the new creations are licensed under the identical terms.

For reprints contact: WKHLRPMedknow_reprints@wolterskluwer.com

\section{Discovery}

In 1979, Robert Weinberg identified that HER2 gene was involved in multiple cancer pathways. Many years later, Dennis Slamon (UCLA) collaborated with Axel Ullrich (Genentech) and showed that HER2 positivity was associated with poor prognosis and trastuzumab improved survival. ${ }^{[4]}$

\section{Approval}

In 1998, trastuzumab was Food and Drug Administration (FDA) approved for the treatment of HER2-positive metastatic breast cancer. In 2006, trastuzumab was FDA approved for the treatment of HER2-positive breast cancer as an adjuvant therapy. In 2010, trastuzumab was FDA approved for the treatment of HER2-positive metastatic gastric cancer.

\section{Human Epidermal Growth Factor Receptor 2 Positivity (ASCO/CAP Guideline)}

Breast cancer and gastroesophageal cancer - HER2 is positive when IHC for HER2 neu is $2+$ and FISH for HER2 neu is positive or IHC $3+$.

\section{Indication}

The National Comprehensive Cancer Network and the European Society of Medical Oncology guidelines recommend trastuzumab for patients with $\geq \mathrm{T} 1 \mathrm{c}$ HER2-positive

How to cite this article: Dhanushkodi M. Trastuzumab: A milestone in human epidermal growth factor receptor 2-positive breast cancer. Indian J Med Paediatr Oncol 2020;41:54-6.

\section{Manikandan Dhanushkodi}

Department of Medical Oncology, Cancer Institute (WIA), Chennai, Tamil Nadu, India

Submitted: 16-Dec-2019 Accepted in Revised Form: 06-Feb-2020

Published: 24-Apr-2020

Address for correspondence: Dr. Manikandan Dhanushkodi, Department of Medical Oncology, Cancer Institute (WIA), 38, Sardar Patel Road, Chennai - 600036 , Tamil Nadu, India.

E-mail: dmani1982@gmail.com

Access this article online

Website: www.ijmpo.org

DOI: 10.4103/ijmpo.ijmpo_252_19 Quick Response Code:

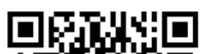


Fritrit

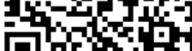




\begin{tabular}{|c|c|c|c|c|c|}
\hline \multicolumn{6}{|c|}{ Table 1: Clinical trials with trastuzumab } \\
\hline Trial & $n$ & Inclusion & Randomization & DFS/PFS & OS \\
\hline $\begin{array}{l}\text { NSABP B31/NCCTG } \\
9831^{[5]}\end{array}$ & 4064 & $\begin{array}{l}\text { HER2-positive operable } \\
\text { breast cancer }\end{array}$ & $\begin{array}{l}\text { Chemotherapy } \\
\text { Chemotherapy }+ \\
\text { trastuzumab }\end{array}$ & $\begin{array}{l}10 \text {-year DFS } 62 \% \text { versus } 74 \% \\
(\mathrm{HR}=0.60 ; \mathrm{CI}=0.53-0.68 \\
P<0.001)\end{array}$ & $\begin{array}{l}10 \text {-year OS } 75 \% \\
\text { versus } 84 \%(\mathrm{HR}=0.63 \text {; } \\
\mathrm{CI}=0.54-0.73 \text {; } \\
P<0.001)\end{array}$ \\
\hline $\operatorname{HERA}^{[6]}$ & 5102 & $\begin{array}{l}\text { HER2-positive } \\
\text { early-stage breast cancer }\end{array}$ & $\begin{array}{l}\text { Chemotherapy } \\
\text { Chemotherapy }+ \\
\text { trastuzumab (1 year) }\end{array}$ & $\begin{array}{l}10 \text {-year DFS } 63 \% \text { versus } 69 \% \\
(\mathrm{HR}=0.76 ; \mathrm{CI}=0.68-0.86)\end{array}$ & $\begin{array}{l}\mathrm{HR}=0.74 \\
\mathrm{CI}=0.64-0.86)\end{array}$ \\
\hline BCIRG $006^{[7]}$ & 3222 & $\begin{array}{l}\text { HER2-positive } \\
\text { early-stage breast cancer }\end{array}$ & $\begin{array}{l}\text { Chemotherapy } \\
\text { Chemotherapy }+ \\
\text { trastuzumab }\end{array}$ & 5-year DFS 75\% versus $84 \%$ & $\begin{array}{l}5 \text {-year OS } 87 \% \text { versus } \\
92 \%\end{array}$ \\
\hline Slamon et al..$^{[8]}$ & 469 & $\begin{array}{l}\text { HER2-positive advanced } \\
\text { breast cancer }\end{array}$ & $\begin{array}{l}\text { Chemotherapy } \\
\text { Chemotherapy }+ \\
\text { trastuzumab }\end{array}$ & $\begin{array}{l}\text { Median PFS } 4.6 \mathrm{~m} \text { versus } 7.4 \\
\mathrm{~m}(P=0.001)\end{array}$ & $\begin{array}{l}\text { Median OS } 20 \mathrm{~m} \\
\text { versus } 25 \mathrm{~m}(P=0.01)\end{array}$ \\
\hline Finher ${ }^{[9]}$ & 232 & $\begin{array}{l}\text { HER2-positive } \\
\text { node-positive or } \\
\text { node-negative high-risk } \\
\text { breast cancer }\end{array}$ & $\begin{array}{l}\text { Weekly trastuzumab for } \\
9 \text { weeks } \\
\text { No trastuzumab }\end{array}$ & $\begin{array}{l}3 \text {-year RFS } 89 \% \text { versus } 76 \% \\
(\mathrm{HR}=0.42 ; \mathrm{CI}=0.21-0.83 ; \\
P=0.01)\end{array}$ & - \\
\hline
\end{tabular}

HER2: Human epidermal growth factor receptor 2, DFS: Disease-free survival, HR: Hazard ratio, CI: Confidence interval, PFS: Progression-free survival, OS: Overall survival

breast cancer in adjuvant setting. Patients with pT1b can be considered for trastuzumab if the tumor is hormone negative or Grade 3. Trastuzumab is preferably given concurrently with a taxane. The key trials on trastuzumab in HER2-positive breast cancer are mentioned in Table 1.

\section{Other Indication}

Trastuzumab-based chemotherapy is recommended in advanced HER2-positive gastric or gastroesophageal junction adenocarcinoma. Addition of trastuzumab to chemotherapy in advanced gastric/gastroesophageal junction adenocarcinoma improves overall survival (OS) by 2 months. ${ }^{[10]}$

\section{Strength}

Trastuzumab is available as 440 and $150 \mathrm{mg}$ vial. The reconstituted vial can be used until 28 days when stored at $2{ }^{\circ} \mathrm{C}-8^{\circ} \mathrm{C}$.

\section{Dose and Administration}

The 3 weekly dose is $8 \mathrm{mg} / \mathrm{kg}$ loading intravenous over $90 \mathrm{~min}$ followed by maintenance $6 \mathrm{mg} / \mathrm{kg}$ over $30 \mathrm{~min}$. The weekly dose is $4 \mathrm{mg} / \mathrm{kg}$ loading intravenous over $90 \mathrm{~min}$ followed by $2 \mathrm{mg} / \mathrm{kg}$ maintenance over $30 \mathrm{~min}$. Subcutaneous trastuzumab has also shown to be noninferior to intravenous trastuzumab. ${ }^{[11]}$ The recommended dose is $600 \mathrm{mg}$ trastuzumab with 10,000 units hyaluronidase Q 3 weekly subcutaneous over 2-5 min. Intrathecal trastuzumab $20-50 \mathrm{mg}$ can be used in HER2-positive leptomeningeal disease. ${ }^{[12]}$

\section{Regimens in Human Epidermal Growth Factor Receptor 2-Positive Breast Cancer}

- $\quad<3 \mathrm{~cm}$, node negative: weekly paclitaxel for 12 cycles along with trastuzumab (1 year) ${ }^{[13]}$
- Node positive and higher stage: TCH (docetaxel, carboplatin, and trastuzumab) or AC (adriamycin and cyclophosphamide) followed paclitaxel with trastuzumab ${ }^{[7]}$

- Advanced/metastatic: THP (docetaxel, trastuzumab, and pertuzumab). ${ }^{[14]}$

\section{Duration}

Trastuzumab is continued lifelong for patients with metastatic disease and 1 year for patients with nonmetastatic disease. Persephone trial in early-stage breast cancer from the UK has shown 6 months of trastuzumab to be non-inferior to 1-year duration. ${ }^{[15]}$ Short-course trastuzumab (weekly for 9 weeks) has shown to improve survival as compared to no trastuzumab. ${ }^{[16,17]}$

\section{Toxicity}

\section{Cardiotoxicity}

Clinical trials have shown that the incidence of clinically significant cardiotoxicity with chemotherapy and trastuzumab was about $2 \%{ }^{[7]}$ The risk factors for trastuzumab-induced cardiotoxicity are prior anthracycline usage, coronary artery disease, baseline systolic dysfunction (left ventricular ejection fraction $<50 \%$ ), diabetes, hypertension, dyslipidemia, and atrial fibrillation. Cardiotoxicity is lesser in patients who received short duration trastuzumab (6 months: $4 \%$ ) as compared to long duration (1 year: $6 \%$ ). ${ }^{[15]}$

\section{Monitoring}

No blood investigations are necessary before administration of trastuzumab. Echocardiogram has to be done before starting trastuzumab, every 3 monthly while on trastuzumab, and 6 monthly for 2 years after completion of trastuzumab. 
Patients who have received prior anthracycline need to be monitored for 5 years after completion of trastuzumab. Trastuzumab should be temporarily withheld if LVEF drop is $>10 \%$ and permanently withheld if patients develop symptomatic heart failure or after 2 withholds.

\section{Biosimilar}

Biosimilars are game-changers in oncology and have made cancer care affordable and cost-effective. In 2017, the FDA approved the first biosimilar trastuzumab (Mylan) based on the Heritage trial. ${ }^{[18]}$ This was a phase 3 randomized controlled trial with 500 patients with HER2-positive metastatic breast cancer, where trastuzumab biosimilar showed equivalent response rate $(69 \%$ for biosimilar and $64 \%$ for innovator) at 24 weeks. The OS was also similar in both groups. ${ }^{[19]}$

\section{Newer anti-HER2 therapy}

FDA approved other anti-HER2 therapy includes lapatinib, trastuzumab emtansine, pertuzumab, neratinib, and trastuzumab deruxtecan. ${ }^{[20]}$ Tucatinib $^{[21]}$ is a newer anti-HER2 therapy that has shown promise in heavily pretreated advanced breast cancer.

\section{Conclusion}

Trastuzumab has significantly improved survival in early, locally advanced, and metastatic HER2-positive breast cancer. It can cause cardiotoxicity and needs periodic monitoring with echocardiogram.

\section{Financial support and sponsorship}

Nil.

\section{Conflicts of interest}

There are no conflicts of interest.

\section{References}

1. Mitri Z, Constantine T, O'Regan R. The HER2 receptor in breast cancer: Pathophysiology, clinical use, and new advances in therapy. Chemother Res Pract 2012;2012:743193.

2. Slamon DJ, Clark GM, Wong SG, Levin WJ, Ullrich A, McGuire WL. Human breast cancer: Correlation of relapse and survival with amplification of the HER-2/neu oncogene. Science 1987;235:177-82.

3. Hudis CA. Trastuzumab - Mechanism of action and use in clinical practice. N Engl J Med 2007;357:39-51.

4. Delaney P. HER-2: The making of herceptin, a revolutionary treatment for breast cancer. J Natl Cancer Inst 1999;91:1329-30.

5. Perez EA, Romond EH, Suman VJ, Jeong JH, Sledge G, Geyer CE Jr, et al. Trastuzumab plus adjuvant chemotherapy for human epidermal growth factor receptor 2-positive breast cancer: planned joint analysis of overall survival from NSABP B-31 and NCCTG N9831. J Clin Oncol 2014;32:3744-52.

6. Cameron D, Piccart-Gebhart MJ, Gelber RD, Procter M, Goldhirsch A, de Azambuja E, et al. 11 years' follow-up of trastuzumab after adjuvant chemotherapy in HER2-positive early breast cancer: Final analysis of the HERceptin Adjuvant (HERA) trial. Lancet 2017;389:1195-205.

7. Slamon D, Eiermann W, Robert N, Pienkowski T, Martin M,
Press M, et al. Adjuvant trastuzumab in HER2-positive breast cancer. N Engl J Med 2011;365:1273-83.

8. Slamon DJ, Leyland-Jones B, Shak S, Fuchs H, Paton V, Bajamonde A, et al. Use of chemotherapy plus a monoclonal antibody against HER2 for metastatic breast cancer that overexpresses HER2. N Engl J Med 2001;344:783-92.

9. Joensuu H, Kellokumpu-Lehtinen PL, Bono P, Alanko T, Kataja V, Asola R, et al. Adjuvant docetaxel or vinorelbine with or without trastuzumab for breast cancer. N Engl J Med 2006;354:809-20.

10. Bang YJ, Van Cutsem E, Feyereislova A, Chung HC, Shen L, Sawaki A, et al. Trastuzumab in combination with chemotherapy versus chemotherapy alone for treatment of HER2-positive advanced gastric or gastro-oesophageal junction cancer (ToGA): A phase 3, open-label, randomised controlled trial. Lancet 2010;376:687-97.

11. Jackisch C, Hegg R, Stroyakovskiy D, Ahn JS, Melichar B, Chen SC, et al. HannaH phase III randomised study: Association of total pathological complete response with event-free survival in HER2-positive early breast cancer treated with neoadjuvant-adjuvant trastuzumab after 2 years of treatment-free follow-up. Eur J Cancer 2016;62:62-75.

12. Figura $\mathrm{NB}$, Long $\mathrm{W}, \mathrm{Yu} \mathrm{M}$, Robinson $\mathrm{TJ}$, Mokhtari $\mathrm{S}$, Etame $\mathrm{AB}$, et al. Intrathecal trastuzumab in the management of HER2+ breast leptomeningeal disease: A single institution experience. Breast Cancer Res Treat 2018;169:391-6.

13. Tolaney SM, Barry WT, Dang CT, Yardley DA, Moy B, Marcom PK, et al. Adjuvant paclitaxel and trastuzumab for node-negative, HER2-positive breast cancer. $\mathrm{N}$ Engl J Med 2015;372:134-41.

14. Swain SM, Baselga J, Kim SB, Ro J, Semiglazov V, Campone M, et al. Pertuzumab, trastuzumab, and docetaxel in HER2-positive metastatic breast cancer. N Engl J Med 2015;372:724-34.

15. Earl HM, Hiller L, Vallier AL, Loi $\mathrm{S}$, McAdam $\mathrm{K}$, Hughes-Davies L, et al. 6 versus 12 months of adjuvant trastuzumab for HER2-positive early breast cancer (PERSEPHONE): 4-year disease-free survival results of a randomised phase 3 non-inferiority trial. Lancet 2019;393:2599-612.

16. Joensuu H, Bono P, Kataja V, Alanko T, Kokko R, Asola R, et al. Fluorouracil, epirubicin, and cyclophosphamide with either docetaxel or vinorelbine, with or without trastuzumab, as adjuvant treatments of breast cancer: Final results of the FinHer Trial. J Clin Oncol 2009;27:5685-92.

17. Sethjiwala T, Dhanushkodi M, Radhakrishnan V, Kalaiarasi JP, Mehra N, Joshi A, et al. Adjuvant short-course trastuzumab in breast cancer. Indian J Gynecol 2019;17:68.

18. Rugo HS, Barve A, Waller CF, Hernandez-Bronchud M, Herson J, Yuan J, et al. Effect of a proposed trastuzumab biosimilar compared with trastuzumab on overall response rate in patients with ERBB2 (HER2)-positive metastatic breast cancer: A randomized clinical trial. JAMA 2017;317:37-47.

19. Waller CF, Manikhas V, Pennella EJ, Bondarenko V, Mukhametshina G, Tiambeng ML, et al. Biosimilar trastuzumab-dkst monotherapy versus trastuzumab monotherapy after combination therapy: Final overall survival (OS) from the phase III HERITAGE Trial. J Clin Oncol 2019;37:1021.

20. Modi S, Saura C, Yamashita T, Park YH, Kim S, Tamura K, et al. Trastuzumab deruxtecan in previously treated HER2-positive breast cancer. N Engl J Med 2019;382:610-21.

21. Murthy RK, Loi S, Okines A, Paplomata E, Hamilton E, Hurvitz SA, et al. Tucatinib, trastuzumab, and capecitabine for HER2-positive metastatic breast cancer. $N$ Engl J Med 2019;382:597-609. 